\title{
MEASURING QUALITY OF MATERNITY SERVICES USING THE SERVQUAL METHOD
}

\author{
Paulina Gajewska ${ }^{1}$, Katarzyna PiskrzyŃSKa ${ }^{2}$ \\ University of Bielsko-Biala (Poland)
}

\begin{abstract}
Quality is the important issue in today's competitive world. In modern institutions, regardless of the type of business, it becomes the basis for its effective functioning; it is a determinant of organizational culture and the success factor. The organization, which offers products or services of poor quality - has no reason to exist as the consumers are becoming more aware of their needs and decide not to purchase products and services of poor quality. The article presents another proposal to assess the quality of maternity services, using the SERVQUAL method.

KEY WORDS: SERVQUAL method, quality of service, measuring service quality.
\end{abstract}

JEL CODES: I11, L84.

\section{Introduction}

Increased awareness of patients, their needs, expectations regarding the health care and intensifying competition in the market of medical services makes the maintenance and development of therapeutic entities. It depends largely on the quality of service offered by them. This quality which relates to all aspects of the functioning of the hospital - the scope of services offered, the manner and the speed of their implementation, organization and process of treatment, the use of modern methods of diagnosis and therapy, etc. The authors of the article recently outlined the method CSI in assessing the quality of services of these services.

Problem: The article presents proposal to assess the quality of maternity services, using the SERVQUAL method. Purpose: the authors of this article recently outlined the method CSI in assessing the quality of services of these services (Gajewska, Piskrzyńska, 2016) and now present the proposal to use another method of helping to shape the quality of maternity services.

Object: The study on SERVQUAL method were covered by three obstetric institutions, facilities located in Bielsko-Biala. Presented analysis is the part of a broader research carried out by Marta Wrzoł and described in the thesis "The importance of quality obstetric services" (July 2016) implemented in the Department of Management at the University of Bielsko-Biala; the work was written under the guidance of scientific dr. Paulina Gajewska. The study was of pilot nature - it was about validation of research and testing procedure for future research in this area. Selected for the following institutions (all located in Bielsko-Biala):

1 Paulina Gajewska - assoc. prof. dr. University of Bielsko-Biala (Poland), Department of Management, Faculty of Management and Transport

Scientific interests: health care services, management problems

E-mail: pgajewska@ath.bielsko.pl

2 Katarzyna Piskrzyńska - assoc. prof. dr. University of Bielsko-Biala (Poland), Department of Management, Faculty of Management and Transport

Scientific interests: health care services, management problems

E-mail: kpiskrzynska@ath.bielsko.pl 
- Regional Hospital - located at 101 Avenue of the Home Army;

- Beskid Oncology Centre - Municipal Hospital name John Paul II - located at ul. Wyspiańskiego 21;

- Medical Center "Esculap" Sp. o.o. - located at ul. Cieszyńskiej 472.

However, in the article, due to editorial requirements, the results of research only for the Provincial Hospital.

Tasks: indication of the usefulness of SERVQUAL method in the assessment of the quality of maternity services, indication of the differences between expectations and experience in maternit services, indication the sequence of corrective actions in maternity services in the analyzed hospital.

Methods. The data were collected using a simplified version of the SERVQUAL questionnaire, so that patients of the maternity wards could complete it quickly and without effort. The form contains 22 questions which were divided into 5 groups: materiality, reliability, responsibility, confidence, empathy.

Subsequently, the weighted arithmetic mean of the expected service and received - then these values are subtracted from each other. To avoid receiving the most negative values of expectations - the expected service was subtracted $(O-R=Q)$. Negative value arises from the using the method SERVQUAL. In the case of service activity usually the client's expectations are on the highest level, so practically the service hardly ever exceeds the expectations and approaches their level. Therefore the same negative results do not prove that the institution is functioning poorly, only large negative values or values worse than competitive organizations suggest the occurrence of problems in the given area.

\section{Quality of service}

Quality is now a big problem of social and economic development in every country and in every aspect of human life. You can talk about the quality of service, quality of product, quality of work, quality of life or quality of processes. Hence, generally understood, quality should be the focus of every human being, irrespective of whether he is the producer, consumer, service provider or recipient (Stoma, 2012). Many authors dealt with the theme of measuring quality during the past two decades (for example, Asher, 1988; Dotchin, Oakland, 1994; Mels et al., 1997; Xie et al., 1998; Wiśniewski, 2001; Candido, Morris, 2001, etc.).

The problems of managing quality of service is an important issue mainly due to the continuous growth of the service sector in the economy. Quality management requires a clear definition of what is the quality of the object is targeted at by the management - in this case the service (Urban, 2007). This concept has not got a satisfying definition yet and the difficulty with making final definition is caused by the fact that the ultimate judge of the quality of services remains a buyer, often directing his or her subjective and often irrational. The basic, widely accepted and consistent with the philosophy of marketing definition of quality of services is: "Quality of service is the degree to meet the expectations of buyers. The service is the quality if the implementation meets or exceeds the expectations of buyers" (Zeithaml, Parasuraman, Berry, 1990).

According to this definition, the most important for assessing the quality of services are the expectations of buyers which represent some cycles run through the following phases (Czubała, Jonas, Smolen, Wiktor, 2006):

- perfect service - the best that you can imagine and realize;

- services contacts desired (attractive) - services of such a standard that customers want to receive;

- $\quad$ service deserved (acceptable) - services which consumers should receive for a specified price;

- minimum services - services such as standard must be achieved.

The difference between expectations for service attractive, and expectations for the level of service that should be given is called the tolerance zone (Figure 1). 


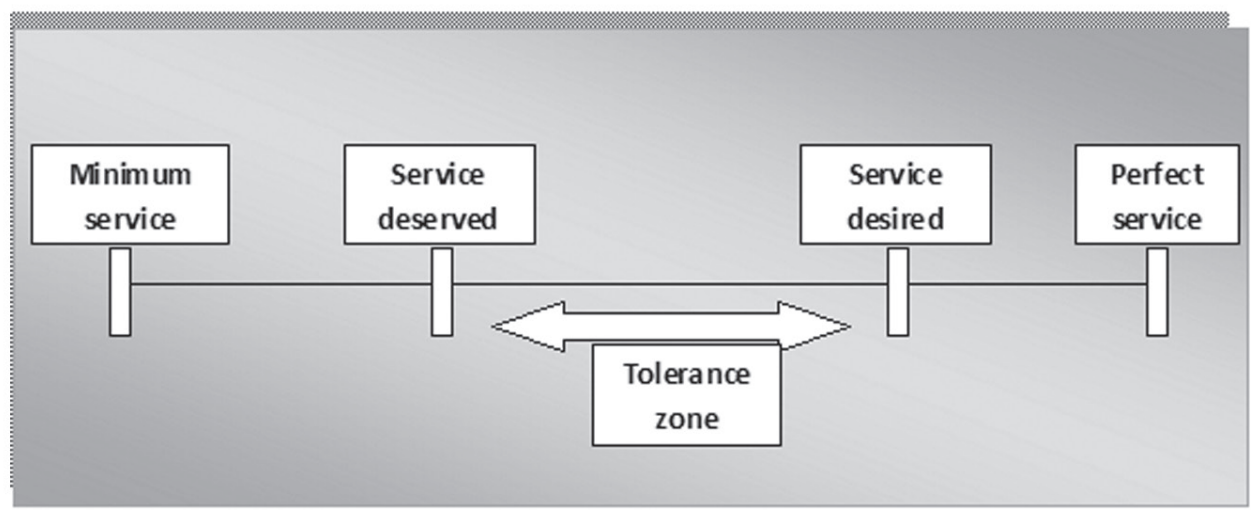

Figure 1. The levels of expectations and tolerance zone consumers to services

Source: Own study based on: Czubała, Jonas, Smolen, Wictor, 2006: 116.

The quality of maternity services is a special type of service because it is associated with a very important event in the life of every future mother - the birth of a child. It is important to ensure that healthcare institution did its best to create the best possible conditions for the delivery and ensure the safety and loving care of the mother and her child. It is particularly important for the development of strategies to improve the level of quality of maternity services, to meet the expectations of patients and their opinions about the level of services received. Regular testing the patients of maternity wards allows you to get information about matters which satisfy them, which causes dissatisfaction and what they expect from the institution.

\section{The SEVQUAL method}

Among the variety of methods described in the literature measuring the level of service quality the most popular is the SERVQUAL method. It is a simple, multi-scale by which you can measure the quality of service from the point of view of the customer to give many hints to the direction of quality improvement (Mazur, 2001).

Service quality (SERVQUAL) is a modern technique for measuring quality in different enterprises and organizations and serves the development of a truly customer - focused management and culture (Gazor et al, 2012).

SERVQUAL is a method of assessing the quality of services developed by American scientist A. Parasurama and his colleagues $-V$. A. Zeithaml and L. L. Berry. It consists of measuring the differences that exist between the quality perceived by the customer and the quality that he expects from the service (Figure 2). This is due to the fact that every buyer imagines potential quality of service before it is completing (on the basis of their own knowledge, past experience, interpersonal communication or exchange of information and experiences).

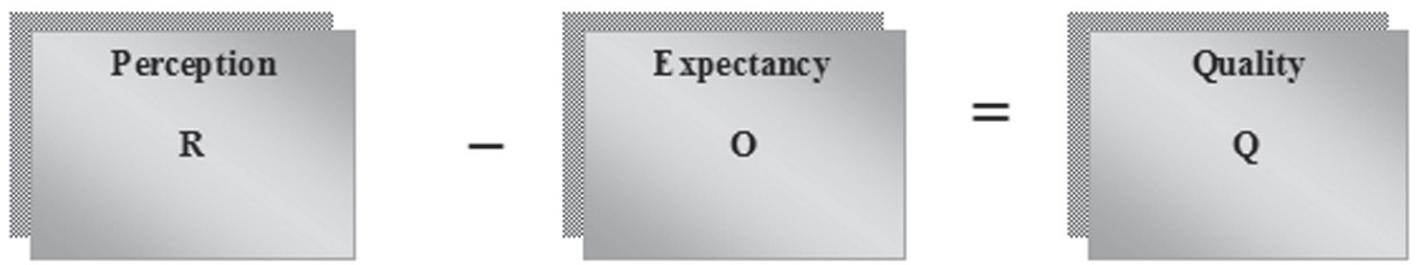

Figure 2. Formula of SERVQUAL model

Source: Own calculations on the basis of Mazur, 2002: 81. 
Analyzing the figure above you can see three situations (Czubała, Jonas, Smoleń, Wiktor, 2006):

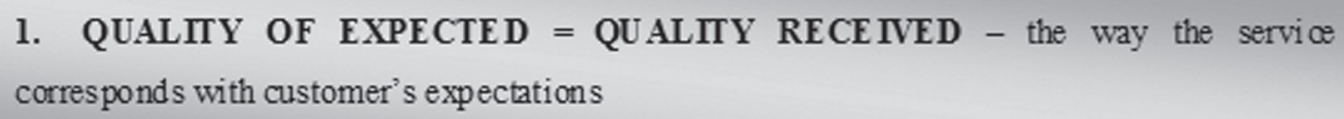

2. QUALITY OF EXPECTE D < QUALIT Y RE CEIVE D - arstomers are pleasantly

surprised and positively evaluate the quality of service

3. EXPECTED QUALITY > QUALITY RECEIVED - customers are dissatisfied and negatively assess the quality of service

Thus the idea of the SERVQUAL method consists of measuring consumers' expectations and their assessment of the service received. They both are used for this research questionnaires based on five criteria describing the quality. They were created by the authors of this concept in the result of their research, which showed that customers use these criteria for self-assessment of service quality. The criteria have been identified as follows (Pluta, 1994; Parasuraman, Zeithaml, Berry, 1988):

- Materiality (material housing services) - the technical quality of the material elements including such aspects as appearance and decor of the premises, equipment, staff, ways for communication.

- Reliability (robustness, responsibility) - understood as the ability to keep the promises, do the service as promised and keep all the conditions of the agreement (eg. time) meticulously.

- Responsibility (ability to respond, the will and the willingness to help and to provide appropriate services) - the service provider should takes into account the expectations and demands of the buyers, act quickly and professionally.

- Certainty (assurance and warranty) - includes criteria such as trust, kindness, competence and security services resulting directly from the knowledge, skills and capacity of the staff.

- Empathy (care, accessibility of services) - individual attention devoted to each client individually that is, combined criteria: availability of customer service, communication skills and understanding (knowledge of consumer issues).

These criteria became the core of the measuring instrument SERVQUAL. All five aspects are measured using a questionnaire including 22 elements. Each aspect is assessed twice in a 5- or 7-point Likert scale. The first part concerns the assessment of the services expected, the second evaluation of the services received, and the aim of the third part of the questionnaire is to establish the extent of the validity of the individual elements (Gilmore, 2006).

The application of SERVQUAL is quite wide - first of all it allows to know the expectations of each customer's service and the level of the gap formed between what the client expects and what the service provides, and hence to determine the quality of services from the customer's perspective. In addition, the SERVQUAL method is known to be the multidimensional one, and can be successfully used both to examine the entire system and its individual components. As stated because the team of Parasuram, SERVQUAL is a framework which, when necessary, can be adapted or supplemented to match the characteristics of either the specific research needs of individual organizations (Stoma, 2012). 


\section{Characteristics of the study sample}

The data were collected from 01.04.2016 to 05.31.2016, the study involved 57 women who gave birth in the last two years. The Provincial Hospital collected 28 questionnaires, 19 in the General Hospital and Medical Center "Esculap" 10 forms. A questionnaire was published on the website 3 , and some went directly to the respondents. Selection of women was accidental.

Of the 57 women who participated in the survey, the vast majority gave birth for the first time - 36 women (63\%), 15 women were a mom for the second time (26\%) and only 6 women. for the third time. Considering patients' age we notice that the largest group of women taking part in research were between 26-36 (40 women), much less were patients aged 18-25 (13 women) and only four respondents were older then 36 . None of the women was under 18 . The research also took into consideration the type of delivery. More than half of the respondents gave birth spontaneously (vaginally) - $63 \%$ of respondents, while $37 \%$ of women completed pregnancy with Caesarean section (Figure 3).

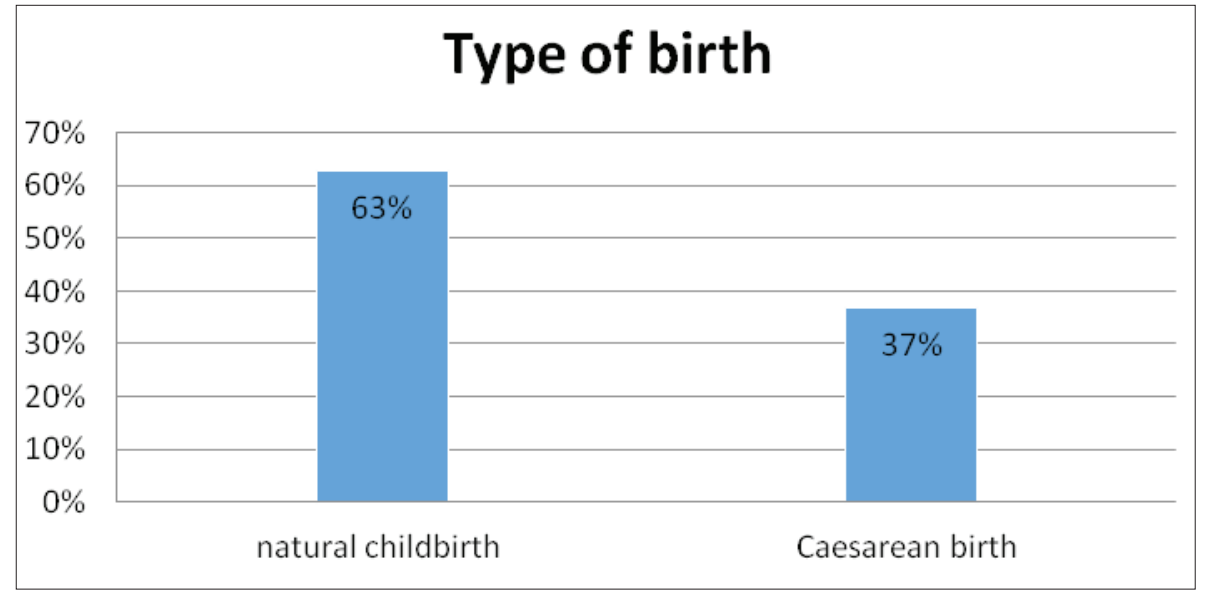

Figure 3. Distribution of the survey sample, due to the type of delivery

Source: Own study based on the research.

We also asked just - be-mothers about their educational background. The survey shows that more than half of the women, 34, has a college education, 22 women graduated from the high school and only one has the vocational education.

4. The quality of maternity services - the SERVQUAL method and results

In order to assess the quality the SERVQUAL questionnaire was carried out. The results were averaged and are reported in the following tables.

Comparing the expectations of patients with the service received it may be noted that in several cases the actual service surpassed the expectations of women.

The least important factor when choosing the medical facility is: the size of the parking lot, cleanliness of hospital, its interior design, neat clothes of the Staff. All those indicators were highly rated by patients, because in these areas the quality exceeds the expectations of women.

Patients also evaluated high: implementation of the service in accordance with medical standards $(-0.14)$; speed of service in the performance of medical procedures $(-0.14)$; and assistance and the availability of medical personnel $(-0.07)$.

These areas also do not require improvement, as the ladies found it highly and service exceeds expectations.

3 Website: http://www.survio.com/survey/d/Q9V0G5B6V4X6J2E6C 
The factors that were evaluated as the worst: understanding of the needs of the patients $(0.61)$, concern (0.57), individual approach to women (0.57), reaction to dissatisfaction (0.57), comply patients' requests (0.57), effective response in case of problems (0.54), politeness of staff (0.54), activities and interests of the patients (0.54).

The results of the study are presented graphically in figure 4 .

Table 1. Average values of the results for the Provincial Hospital in Bielsko-Biala

\begin{tabular}{|llccc|}
\hline No. & \multicolumn{1}{|c}{ Factor } & $\begin{array}{c}\text { The test result on the } \\
\text { customer's expectations } \\
\text { of a service }\end{array}$ & $\begin{array}{c}\text { The test result on the } \\
\text { actual performance } \\
\text { of the service }\end{array}$ & $\begin{array}{c}\text { The difference } \\
\text { (expectations - } \\
\text { experience) }\end{array}$ \\
\hline $\mathbf{1}$ & Interior hospital & $\mathbf{3 . 1 1}$ & $\mathbf{3 . 9 6}$ & $\mathbf{- 0 . 8 6}$ \\
\hline $\mathbf{2}$ & Modern medical equipment & 4.82 & 4.50 & 0.32 \\
\hline $\mathbf{3}$ & Neat appearance of staff & $\mathbf{3 . 7 1}$ & $\mathbf{4 . 2 5}$ & $\mathbf{- 0 . 5 4}$ \\
\hline $\mathbf{4}$ & Cleanliness hospital & $\mathbf{3 . 1 1}$ & $\mathbf{4 . 2 5}$ & $\mathbf{- 1 . 1 4}$ \\
\hline $\mathbf{5}$ & The size of the parking lot & $\mathbf{2 . 7 1}$ & $\mathbf{4 . 4 6}$ & $\mathbf{- 1 . 7 5}$ \\
\hline $\mathbf{6}$ & $\begin{array}{l}\text { The service complies with the } \\
\text { standards }\end{array}$ & $\mathbf{3 . 9 6}$ & $\mathbf{4 . 1 1}$ & $\mathbf{- 0 . 1 4}$ \\
\hline $\mathbf{7}$ & Reliability & 4.61 & 4.18 & 0.43 \\
\hline $\mathbf{8}$ & Responding in case of problems & 4.57 & 4.04 & 0.54 \\
\hline $\mathbf{9}$ & Support and availability of staff & $\mathbf{3 . 5 0}$ & $\mathbf{3 . 5 7}$ & $\mathbf{- 0 . 0 7}$ \\
\hline $\mathbf{1 0}$ & Speed of service & $\mathbf{3 . 5 4}$ & $\mathbf{3 . 6 8}$ & $\mathbf{- 0 . 1 4}$ \\
\hline $\mathbf{1 1}$ & Fulfilling the requests of patients & 3.89 & 3.32 & 0.57 \\
\hline $\mathbf{1 2}$ & The reaction to dissatisfaction & 3.57 & 3.00 & 0.57 \\
\hline $\mathbf{1 3}$ & Expertise and professionalism & 4.64 & 4.25 & 0.39 \\
\hline $\mathbf{1 4}$ & Courtesy of staff & 3.96 & 3.43 & 0.54 \\
\hline $\mathbf{1 5}$ & Medical knowledge & 4.29 & 3.96 & 0.32 \\
\hline $\mathbf{1 6}$ & Atmosphere of trust & 3.93 & 3.54 & 0.39 \\
\hline $\mathbf{1 7}$ & The behavior of intimacy & 4.29 & 3.82 & 0.46 \\
\hline $\mathbf{1 8}$ & Individual approach & 4.11 & 3.54 & 0.57 \\
\hline $\mathbf{1 9}$ & Care & 4.07 & 3.50 & 0.57 \\
\hline $\mathbf{2 0}$ & $\begin{array}{l}\text { Activities in the interest } \text { po the } \\
\text { patient }\end{array}$ & 4.25 & 3.71 & 0.54 \\
\hline $\mathbf{2 1}$ & Understanding needs & 4.29 & 3.68 & 0.61 \\
\hline $\mathbf{2 2}$ & Empathy & 3.79 & 3.43 & 0.36 \\
\hline & & & \\
\hline
\end{tabular}

Source: Own study based on the research.

Analyzing the chart above you can see that the gap between expectations and the actual situation is not large, and in some cases received service exceeded expectations.

The following table presents the average values of the results obtained in terms of the factors determining the level of quality of service. 


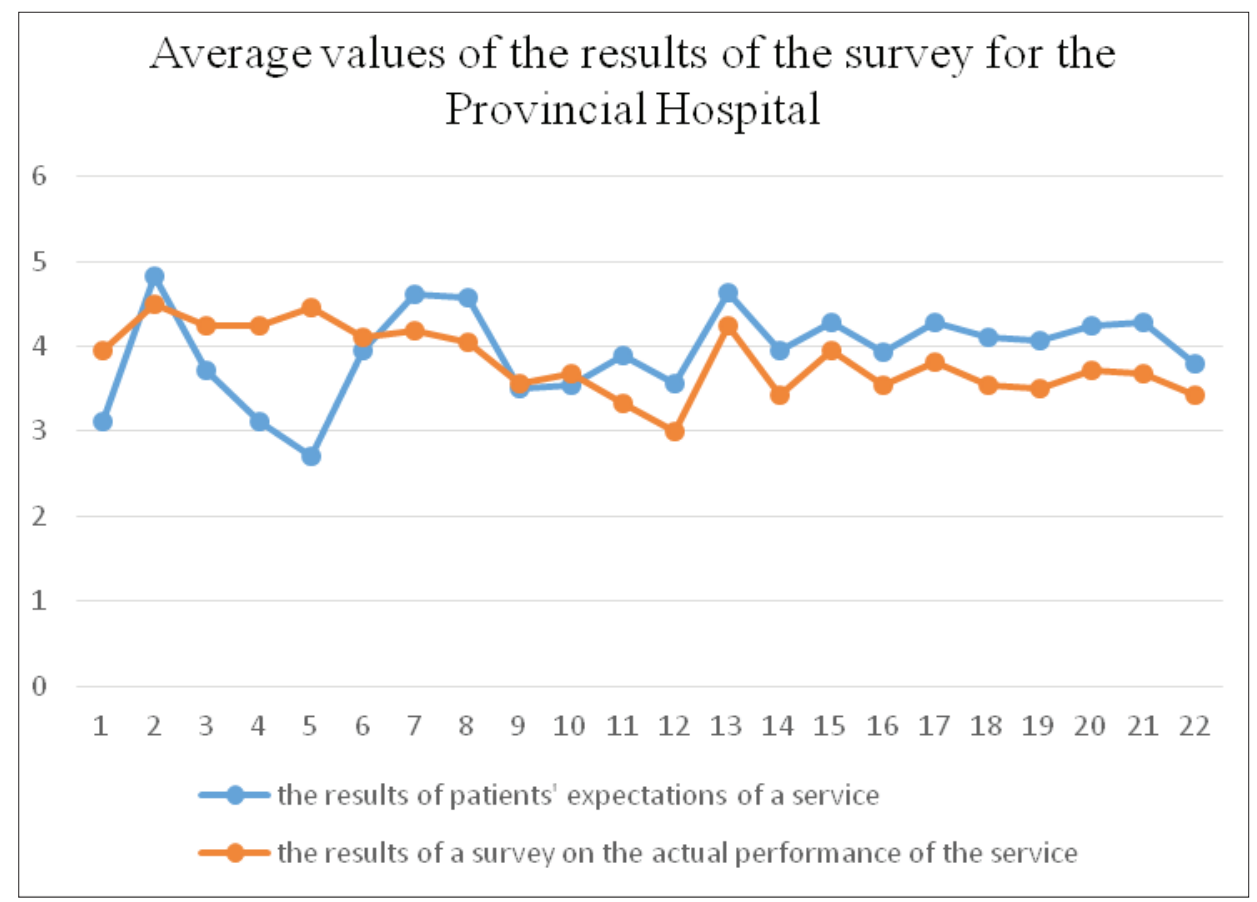

Figure 4. Average values of the results of the survey for the Provincial Hospital

Source: Own study based on the research.

Table 2. Average values of the results divided into groups for the Provincial Hospital

\begin{tabular}{|lccc|}
\hline $\begin{array}{c}\text { Determinant of the level of } \\
\text { quality }\end{array}$ & $\begin{array}{c}\text { The test result on the } \\
\text { customer's expectations of } \\
\text { a service }\end{array}$ & $\begin{array}{c}\text { The test result on the } \\
\text { actual performance of } \\
\text { the service }\end{array}$ & $\begin{array}{c}\text { The difference } \\
\text { (expectations - } \\
\text { experience) }\end{array}$ \\
\hline Materiality & 3.49 & 4.29 & $-\mathbf{0 . 7 9}$ \\
\hline Reliability & 4.38 & 4.11 & 0.27 \\
\hline Responsibility & 3.63 & 3.39 & 0.23 \\
\hline Certainty & 4.22 & 3.80 & 0.42 \\
\hline Empathy & 4.10 & 3.57 & $\mathbf{0 . 5 3}$ \\
\hline
\end{tabular}

Source: Own study based on the research.

The above table indicates in which group there is the largest gap between expectations and actual service, and in which it is the smallest.

The best were factors from the group of materiality, because they exceeded the expectations of women $(-0,79)$, however there is the biggest difference between the qualities of empathy group $(0.53)$, and the smallest in the group of responsibility (0.23). Figure 5 graphically illustrates these differences. 


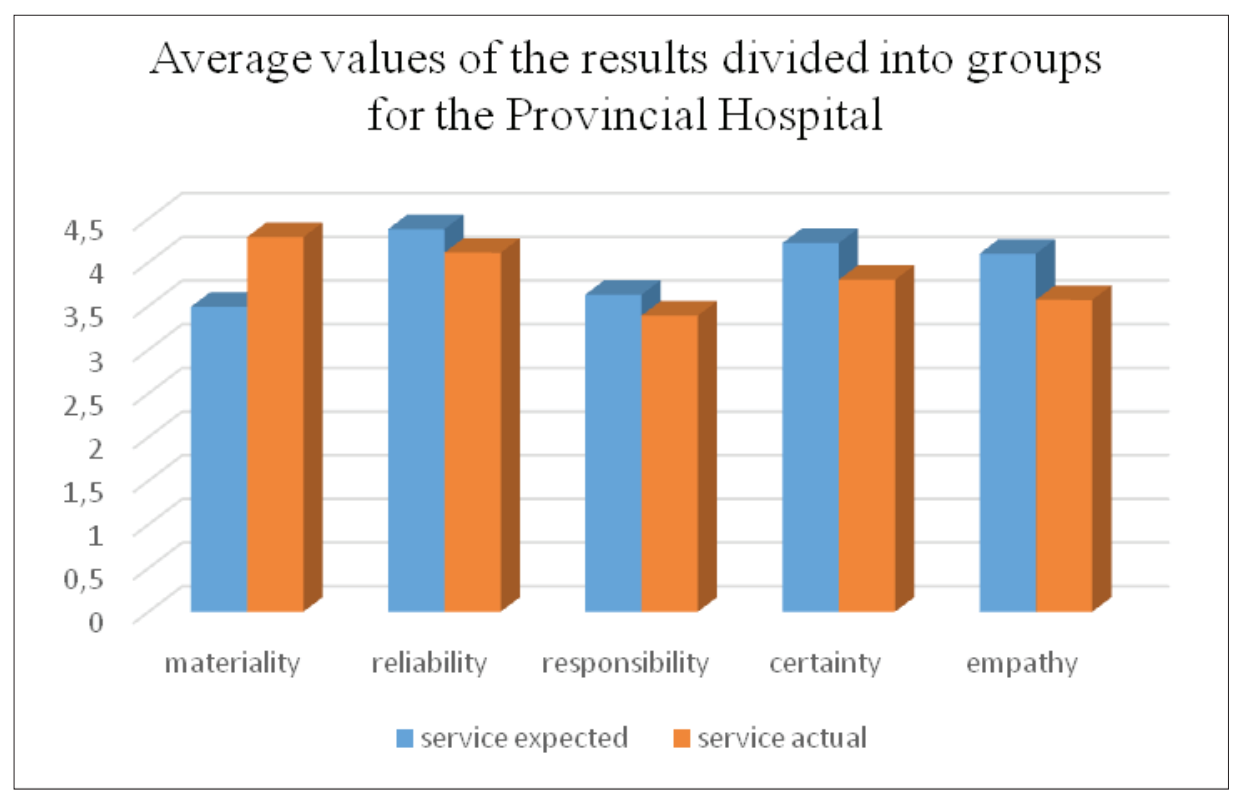

Figure 5. Average values of the results divided into groups for the Provincial Hospital

Source: Own study based on the research.

The table below shows the areas where the expectations of patients:

- have been complied or exceeded (the difference between expectations and experience was less or equal 0.15)

- and those where the facts very different from the expectations disparity between the expectations and the experience was greater than or equal to 0.56 ).

Table 3. Areas that meet the expectations of patients, the highest and lowest

Areas which meet the expectations of patients to the greatest extent

Areas which meet the expectations of the least

\begin{tabular}{|c|c|}
\hline \multicolumn{2}{|c|}{ Regional Hospital } \\
\hline 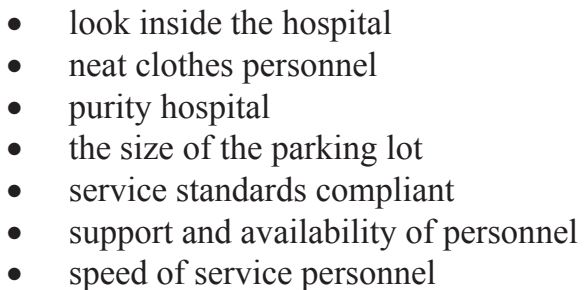 & $\begin{array}{l}\text { - } \text { meet the requests of patients } \\
\text { - } \quad \text { response to dissatisfaction } \\
\text { - } \quad \text { act in the interest of women } \\
\text { - } \quad \text { understanding of the needs of patients }\end{array}$ \\
\hline
\end{tabular}

Source: Own results

In the audited Provincial Hospital there are large discrepancies between the expected and the received service in areas such as:

- readiness and willingness to answer questions, fulfill requests of patients;

- individual approach to women;

- promote the interests of women;

- understanding of the needs of patients.

The hospital management should strive to improve the quality of assessment in the areas identified by patients, comply their expectations on the lowest level. Therefore, hospital staff should pay special attention to the needs of women, and, if possible, provide them with the-required help. It is important to treat each just-become-mother individually because, as you know, a woman in the postpartum period requires a special 
interest, and sometimes patience from hospital employees. In addition to medical service, workers should develop such capabilities as: a sense of empathy, understanding and trust to comply patients' expectations.

\section{Conclusions}

Healthcare institutions belong to the organization for which providing the highest quality of services is a priority, because good quality is reflected in the health, confidence, security, and above all the patient's life. Both the use of the possibilities offered by a well-thought out and planned studies of patient satisfaction, and concentrating a wide range of activities on the provision of services focused on patients allows faster and more efficient activities and better adaptation to the changing needs of beneficiaries, and thus contributes to their satisfaction and to improvement of the quality of health care facilities.

With the survey, SERVQUAL method, noted that the area where expectations differ significantly from the service received and at the same time requiring improvement, the whole sphere of interaction between the patient and the medical staff. The sense of security during the stay on maternity ward and patient satisfaction are important components of quality of service. Every mother would like to experience the birth of her baby, being surrounded by the care in accordance with their expectations and current trends in obstetrics, what's more, the care provided by qualified and well - educated people who are responsible for the health and life of mother and baby. It is important for nurses and midwives to surround "freshly baked mom" carefully because for every woman situation is exeptional and also very stressful. Health care is an area in which all participants should do their best to provide the highest quality of their services. Keep in mind that the primary value, applied to medical activities is health, the value of which money cannot buy - health is priceless.

\section{References}

Asher, J. M. (1988). The cost of quality in service industries. International Journal of Quality and Reliability Management,Vol. 5 (5), p. 38-46.

Candido, C. J. F., Morris, D. S. (2011). The implications of service quality gaps for strategy implementation. Total Quality Management, Vol. 12, p. 825-833.

Czubała, A., Jonas, A., Smolen, T., Wictor, J. W. (2006). Marketing services. Publishing Economics Wolters Kluwer. Krakow.

Dotchin, J. A., Ockland, J. S. (1994). Total quality management in services. International Journal of Quality and Reliability Management, Vol. 11 (3), p. 27-42.

Gajewska, P., Piskrzyńska, K. (2016). CSI Method of Assessing Patient Satisfaction in Selected Maternity Wards. Journal of Modern Accounting and Auditing, Vol. 12, No. 5, Serial No. 132, p. 277-283.

Gilmore, A. (2006). Services. Marketing and management. Polish Economic Publishing House.

Mazur, J. (2001). Managing marketing services. Difin, Warsaw.

Mazur, J. (2002). Managing marketing services. Warsaw.

Mels, G., Boshoff, C., Nel, D. (1997). The dimensions of sevice quality: the original European perspective revisited. The Service Industries Journal, Vol. 17 (1), p. 173-189.

Parasuraman, A., Zeithaml, V. A., Berry, L. L. (1988). SERVQUAL: A Multiple - Item Scale for Measuring Customer Perceptions of Service Quality. Journal of Retailing, Vol. 64, No. 1, p. 12-40.

Pluta-Olearnik, M. (1994). Marketing services, PWE, Warszawa.

Stoma, M. (2012). Models and methods of measuring the quality of services. Q \& R Poland.

Urban, W. (2007). Definitions of quality of service - differences and their causes. Problems of Quality, No. 3, p.

Urbaniak, A. M. (2013). Application of SERVQUAL to evaluate the quality of leisure services. ZNUV, No. 32, p. .

Wiśniewski, M. (2001). Assesing customer satisfaction with local authority services using SERVQUAL. Total Quality Management, Vol. 12, p. 995-1002.

Xie, M., Goh, T. N., Wang, H. (1998). Quality dimensions of internet search engines. Journal of Information Science, Vol. 24 (5), p. 87-94.

Zeithaml, V. A., Parasuraman, A., Berry, L. (1990). Delivering Quality Service: Balancing Customer Perceptions and Expectations. Free Press, New York. 


\section{MOTINYSTÉS PASLAUGŲ KOKYBÉS MATAVIMAS SERVQUAL METODU}

Paulina Gajewska, Katarzyna Piskrzyńska

Bielsko-Biala universitetas (Lenkija)

Santrauka

Kokybė konkurencingame šiandienos pasaulyje yra ypač svarbi. Moderniose institucijose, nepaisant jų srities, tai yra viena pagrindinių efektyvaus funkcionavimo ašių, lemianti institucijos organizavimo kultūrą ir sėkmingumą. Organizacija, siūlanti prastos kokybės produktus ar paslaugas, netenka galimybių egzistuoti, nes vartotojai vis geriau supranta savo poreikius ir nutaria nepirkti produktų ar paslaugų, kurių kokybė menka. Šiame straipsnyje pateiktas dar vienas pasiūlymas, kaip pamatuoti motinystės paslaugų kokybę Servqual metodu. Atlikus apklausą Servqual metodu, gauti rezultatai atskleide, kad pacienčių ir medikų požiūriai apie gaunamų paslaugų kokybę ir turimi lūkesčiai gerokai skiriasi. Pacientės turi daug daugiau lūkesčių, negu mano medikai. Saugumo jausmas apsistojus gimdymo namuose ir pacienčių pasitenkinimas yra svarbūs kokybiškų paslaugų veiksniai. Kiekviena motina gimdydama norètų būti apsupta tokios globos, kuri atitiktų jos lūkesčius, žinoma, norètų, kad būtu taikoma naujausi akušerijos mokslo pasiekimai, o asmenys, atsakingi už gimdyvès ir kūdikio sveikatą bei gyvybę, būtų kvalifikuoti ir išsilavinę. Yra svarbu, kad seselès ir akušerès atsargiai elgtųsi su „naujai iškepta mama“, nes kiekviena moteris šioje situacijoje elgiasi skirtingai, tai yra streso kupinas metas. Sveikatos apsauga yra sritis, kurioje visi darbuotojai turètų stengtis savo darbą atlikti kuo geriausiai. Nereikètų pamiršti, kad priminė sveikatos apsaugos vertybė yra sveikata, o sveikatos už pinigus nenusipirksi, ji yra neịkainojama.

PAGRINDINIAI ŽODŽIAI: Servqual metodas, paslaugu kokybé, paslaugu kokybès matavimas.

JEL KLASIFIKACIJA: I11, L84.

Received: 2016.09.02

Revised: 2016.09.20.

Accepted: 2016.10.01 